
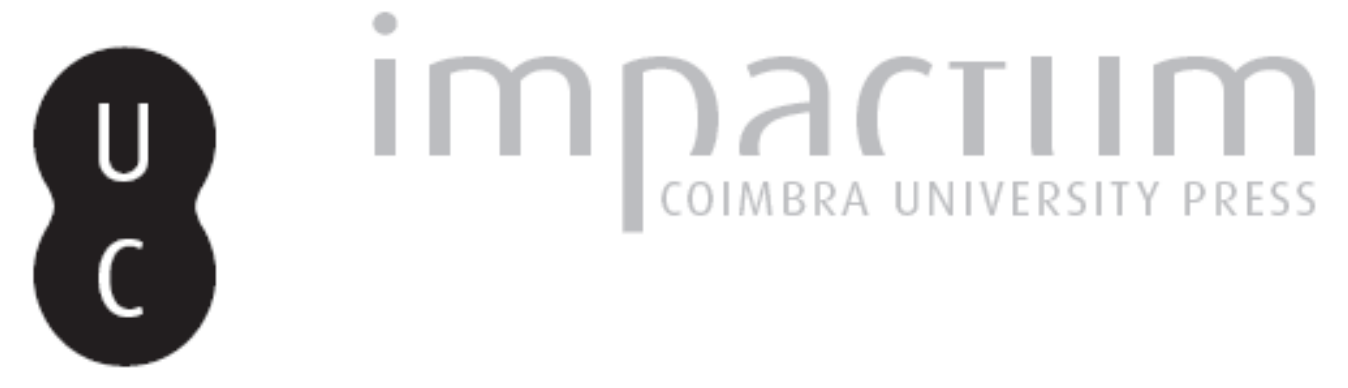

\title{
Foi Heródoto egiptólogo?: construções da utopia no livro Il de Heródoto
}

\author{
Autor(es): $\quad$ Santos, Nídia Catorze
}

Publicado por: Centro de História da Universidade de Lisboa

URL persistente:

URI:http://hdl.handle.net/10316.2/23790

DOI:

DOI:http://dx.doi.org/10.14195/0871-9527_19_13

Accessed : $\quad$ 26-Apr-2023 13:19:35

A navegação consulta e descarregamento dos títulos inseridos nas Bibliotecas Digitais UC Digitalis, UC Pombalina e UC Impactum, pressupõem a aceitação plena e sem reservas dos Termos e Condições de Uso destas Bibliotecas Digitais, disponíveis em https://digitalis.uc.pt/pt-pt/termos.

Conforme exposto nos referidos Termos e Condições de Uso, o descarregamento de títulos de acesso restrito requer uma licença válida de autorização devendo o utilizador aceder ao(s) documento(s) a partir de um endereço de IP da instituição detentora da supramencionada licença.

Ao utilizador é apenas permitido o descarregamento para uso pessoal, pelo que o emprego do(s) título(s) descarregado(s) para outro fim, designadamente comercial, carece de autorização do respetivo autor ou editor da obra.

Na medida em que todas as obras da UC Digitalis se encontram protegidas pelo Código do Direito de Autor e Direitos Conexos e demais legislação aplicável, toda a cópia, parcial ou total, deste documento, nos casos em que é legalmente admitida, deverá conter ou fazer-se acompanhar por este aviso.

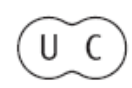



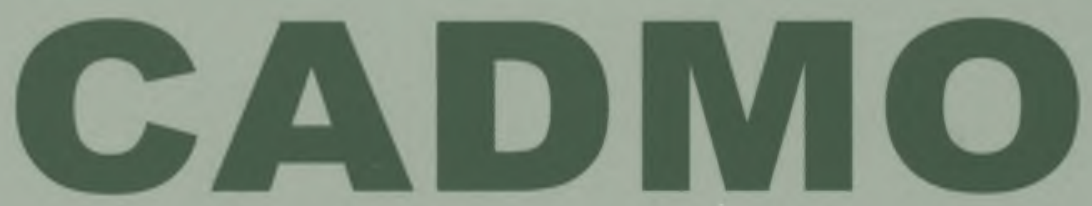

Revista de História Antiga

\author{
Centro de História \\ da Universidade de Lisboa
}

19

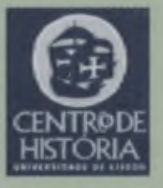

430 =

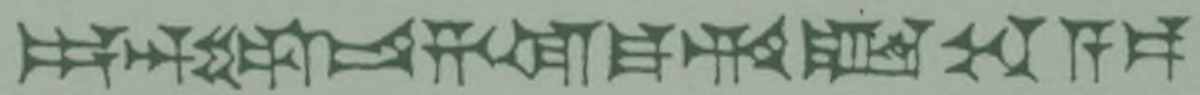

MHNIN AEI $\Delta$ E $\Theta E A ~ \Pi H \Lambda H I A \triangle E \Omega$ 


\title{
FOI HERÓDOTO EGIPTÓLOGO? CONSTRUÇÕES DA UTOPIA NO LIVRO ॥ DE HERÓDOTO
}

\author{
NÍDIA CATORZE SANTOS \\ Universidade de Lisboa \\ nmcsantos@msn.com
}

\begin{abstract}
«Já vi edições das Histórias que trazem na capa um retrato esculpido do autor. Uma estátua encontrada num museu francês. Mas não é assim que eu imagino Heródoto.

Vejo-o mais como um desses homens secos do deserto que viajam de oásis em oásis, comerciando lendas como se as lendas pudessem ser trocadas por sementes, consumindo tudo sem desconfiança, compondo a pouco e pouco uma miragem.»

Michael Ondaatje, O Paciente Inglês, p. 130
\end{abstract}

\section{Resumo}

O Livro II das Histórias de Heródoto destaca-se pela sua longa digressão pelo Vale do Nilo e foi, desde sempre, analisado sob um ponto de vista egiptológico. Este artigo tem como objectivo propor um olhar a partir da literatura grega e de alguns dos seus relatos de utopias.

Palavras-chave: Heródoto; literatura grega; utopia; Egipto.

\section{Abstract}

In the Histories of Herodotus, the Second Book stands out by its long digression on the Nile Valley and has been studied mainly from the Egyptological point of view. This article's purpose is to read it through Greek Literature perspective and through some of its utopias.

Key-words: Herodotus; Greek literature; utopia; Egypt. 


\section{Status quaestionis}

"O Egipto é um dom do Nilo". Esta célebre afirmação assinalou, para muitos de nós, o primeiro contacto com o Vale do Nilo e, em simultâneo, com o próprio Heródoto, cujo espírito Ondaatje soube evocar como ninguém.

As palavras do escritor canadiano, numa obra plena de referências clássicas como é The English Patient, assumem uma ressonância homérica que relembram que os "viandantes necessitados de comida mentem, sem qualquer vontade de dizer a verdade" (Od. 14. 124-124). Foram, no entanto, os viandantes, de Homero e Ondaatje, onde também se inclui Heródoto, que movidos por uma sede de descoberta e conhecimento deram "novos mundos ao mundo", para repetir um cliché também famoso. Tal como Ulisses (Od. 1. 3-4), também o "pai da História" conheceu muitos povos, os seus espíritos e cidades. Como afirma de forma simples no seu proémio, "esta é a exposição das investigações de Heródoto de Halicarnasso, para que os feitos dos homens se não se desvaneçam com o tempo, nem fiquem sem renome as grandes e maravilhosas empresas, realizadas quem pelos Helenos quer pelos Bárbaros, e sobretudo por que entraram em conflito uns com os outros".

No desejo de preservar a memória para a posteridade, legou-nos uma descrição vívida e colorida do mundo mediterrâneo, no século $\mathrm{V}$ a. C., das estórias e lendas que aí podiam ser ouvidas, e que o autor transmite nas várias versões que ouviu. Cabe-nos a nós, distantes leitores formar uma opinião sobre elas. Esta é uma das características que sobressaem na sua escrita, mas que nos deixam com a eterna interrogação: fê-lo porque considerava importante anotar todas as versões e tradições que ouvia sobre um determinado tema ou porque simplesmente não tinha sentido crítico (Thuc. 1. 22), ou pior, alimentava simpatias filo-bárbaras?

De assinalar que muitas destas tradições poderiam ter-se perdido na noite do tempo e da História se ele não as considerasse dignas de nota. A simpatia e respeito com que retrata as culturas e costumes dos "Outros" reservaram-lhe, à semelhança de Anacársis, o sábio cita (Hdt. 4. 76), um destino cruel, no estileto dos seus sucessores (Plut., Mor. 857a). E em mais nenhum livro das Histórias estas críticas foram mais sentidas do que no livro II.

A primeira leitura resulta sempre desconcertante. Reconhecemos os nomes de quase todos os faraós, mas a cronologia não está cor- 
recta, e estranha-se a atmosfera descontraída e pouco régia que rodeia alguns dos monarcas, nada habitual nos manuais de egiptologia, mas que nos cativa pela sua prosa elegante.

Devido à temática e características particulares ${ }^{(1)}$, este livro tem sido estudado predominantemente sob um ponto de vista egiptológico ${ }^{(2)}$, apesar da explosão a que se assistiu na última década nos estudos herodotianos. Efectivamente, durante séculos esta foi a mais completa e mais antiga fonte sobre o Egipto. Chegou mesmo a ser a única disponível para o estudo do Egipto faraónico. Para esta situação parece também ter contribuído a divisão alexandrina da obra em nove livros. A concentração da descrição do Egipto, ainda que a conclusão abarque os primeiros dezassete capítulos do livro III, revelou-se um obstáculo à sua integração na obra alargada, mesmo quando são reconhecidos paralelos, como acontece no caso da simetria de opostos que perpassa toda a obra do historiador, e que pode ser encontrada na descrição do Egipto e da Cítia, a quem foram dedicados dois longos logoi. Localizados nos extremos do mundo (respectivamente a Sul e Norte), ambos partilham a resistência em tomar costumes estrangeiros (Hdt. 2. 79, 91; 4. 76). Enquanto no Egipto nunca chove (Hdt. 2. 14) e a inundação ocorre na época em que todos os outros rios secam (Hdt. 2. 19), na Cítia chove no Verão (Hdt. 4. 28). Enquanto o Nilo une o país ao seu redor e é uma excelente via de comunicação (Hdt. 2. 96), os rios dividem a Cítia, protegendo-a de viajantes e invasores (Hdt. 4. 47).

Se não podemos, e não é de todo nossa intenção, ignorar a profunda influência que Heródoto teve na génese e desenvolvimento da Egiptologia, procuramos nestas breves linhas abordar o logos egípcio, na perspectiva da literatura grega, principalmente nos aspectos utópicos que revestem a sua narrativa.

\section{Construções da utopia}

$\mathrm{Na}$ longa descrição que dedica ao Egipto, Heródoto apresenta um país real, com o qual os Gregos ao longo dos séculos estabeleceram laços comerciais (Hdt. 2. 178 179), dinásticos (Hdt. 2. 181) e de amizade (Hdt. 2. 152, 178, 180, 182). Tais relações incluem-se, inclusive, entre as fontes ouvidas e consultadas pelo escritor (Hdt. 2. 32, $45,55,143)$. O relato sobressai como a confluência de várias utopias homéricas, e não só, envolto ainda na felicidade da Idade do Ouro (Hes., Op. 116-120, 170-173). Estas particularidades são acentuadas 
pela localização geográfica, fertilidade e governação, que concretizam simultaneamente a ambiguidade semântica da palavra grega: eu topos (bom lugar) e ou topos (não lugar), cujos significados têm sido utilizados para formular um local imaginário, frequentemente idealizado e sem existência real.

Distante, mas em simultâneo, próximo das fronteiras da oikoumene, o país tem características notáveis, um clima idiossincrático ${ }^{(3)}$, o qual faz dos Egípcios o povo mais saudável do mundo, logo depois dos Líbios (Hdt. 2. 77), com costumes contrários aos de todos os outros povos $^{(4)}$ e possuidor dos monumentos mais indescritíveis de qualquer outro lugar no mundo. De facto, a comparação de alguns destes monumentos, como o Labirinto e as Pirâmides, com o conjunto de todas as cidadelas e monumentos públicos dos Gregos, evidencia que menos trabalho e dinheiro foram gastos na sua edificação do que na construção do Labirinto, apesar de os templos de Éfeso e Samos serem estruturas notáveis (Hdt. 2. 35; 148) $)^{(5)}$.

O Egipto é uma dádiva que os Egípcios receberam do Nilo como presente (Hdt. 2. 5). Dependem do rio para obterem as suas colheitas, através da inundação anual e que permite aos habitantes do Delta serem, entre todos os povos do mundo, incluindo o resto do Egipto, os que com menos esforço granjeiam as suas colheitas. Depois de o rio inundar os campos e se retirar, semeiam-nos e enviam os porcos para enterrar as sementes e, após o fim destas tarefas, resta-lhes esperar pela época da colheita (Hdt. 2. 14). Apesar de estarem sedentarizados, praticarem a agricultura, terem uma cultura antiga e refinada, organizada em torno das cidades, os Egípcios mantiveram muitos dos valores que caracterizam os nobres selvagens das Histórias, como os Persas (antes da ascensão de Ciro), os Masságetas ou os Etíopes "de longa vida": são hospitaleiros, justos, respeitam os deu$\operatorname{ses}^{(6)}$ e vestem-se de forma simples, com túnicas de linho e capas de lã (Hdt. 2. 81). Os Egípcios não consumiam vinho, mas uma cerveja feita de cevada, comiam peixe seco ao sol e salgado, codorniz e aves (Hdt. 2. 77), sendo que, entre eles, os habitantes dos pântanos que suplementavam a sua dieta com peixe e papiro, encontraram no lótus, uma planta que cresce nas águas no rio, uma fonte barata de alimento, e que cozinhavam de diferentes formas (Hdt. 2. 92). Entre os Gregos, acreditava-se que o lótus, "doce como o mel», tinha o dom de fazer o esquecer a quem o comesse o desejo de regressar à pátria, como o descobriram Ulisses e os seus companheiros, ao desembarcarem no país dos Lotófagos (Od. 9. 84-97). 
A evocação do imaginário homérico está aqui bem presente, sendo evidentes os paralelos com Esquéria (Od. 7. 112-132) e em especial com a ilha dos Ciclopes (Od. 9. 106-111), onde os seus habitantes, confiantes nos deuses, não aram nem semeiam a terra, mas tudo ali cresce e dá fruto ${ }^{(7)}$.

A concepção geográfica jónica considerava apenas o Delta, que se prolongava até à cidade de Cercasoro, como Egipto, atribuindo o restante território à Líbia ou à Arábia (Hdt. 2. 15). Esta visão jónica e grega colide com a divisão do mundo por si definida, quando afirmam que este se divide em três partes - Europa, Ásia e Líbia - uma vez que o Delta egípcio não pertence nem à Ásia nem à Líbia. Assim, os geógrafos jónicos deveriam, na opinião de Heródoto, acrescentar uma quarta parte, pois, de acordo com a sua descrição, o Nilo não é a fronteira entre estes dois continentes, mas divide-se e corre em volta, com o Delta a situar-se precisamente entre ambos (Hdt. 2. 16). Rodeado por montanhas do lado líbio e arábico ${ }^{(8)}$, o país é extenso e composto por planícies, água e pântanos, desde a costa até Heliópolis. A partir desta cidade, o rio torna-se estreito, não há muita terra, mesmo depois de quarenta dias a navegar rio acima, após o que se volta a alargar uma vez mais (Hdt. 2. 7-8).

Ao contrário da vizinha Líbia, o país não tem muita vida selvagem e todos os animais são considerados sagrados. Cada espécie tem um tratador nomeado para cuidar dela e o cargo, que pode ser desempenhado por homens ou mulheres, é hereditário. (Hdt. 2. 65). Entre a fauna, encontramos o crocodilo (Hdt. 2. 68-70, o hipopótamo (Hdt. 2. 71) e a lontra (Hdt. 2. 72). Heródoto cita ainda a fénix, que se assemeIha no tamanho e na aparência a uma águia, com penas douradas e vermelhas, reconhecendo, todavia, que apenas a viu numa pintura, uma vez que raras são as ocasiões em que visitam o país. De acordo com os sacerdotes de Heliópolis, aparecem uma vez a cada quinhentos anos, aquando da morte do progenitor. Abandonam a sua pátria na Arábia em direcção aos santuário do Sol, no Egipto, para lá sepultar o pai, que transportam envolto num ovo de mirra (Hdt. 2. 73).

O Nilo intrigou profundamente o historiador de Halicarnasso, que confessa a sua incapacidade para encontrar informações sobre o rio e suas misteriosas origens, quer entre os sacerdotes egípcios quer entre os líbios, que explicassem a razão de a inundação ocorrer durante o solstício de Verão e prolongar-se por cem dias (Hdt. 2. 19) ${ }^{(9)}$. Durante a inundação, o país transforma-se em mar aberto e as suas cidades ${ }^{(10)}$ assemelham-se às ilhas do Egeu, elevando-se acima das águas. No 
fim dos cem dias, as águas retiram-se finalmente, exibindo desta forma um comportamento contrário a todos os demais rios (Hdt. 2. 97). Uns cireneus contaram-Ihe que, aquando de uma visita ao oráculo de Amon, conversaram com Etearco, o monarca local, sobre o mesmo tema. Este, por sua vez, contou-Ihes o que tinha ouvido a uns Namamones, uma tribo líbia. Segundo o relato destes, alguns elementos da sua tribo empreenderam uma expedição para explorarem o deserto líbio. Depois de percorrerem as zonas desertas e uma área infestada por animais selvagens, avistaram, ao fim de muitos dias, árvores que cresciam na planície. Quando tentaram colher os frutos que nelas cresciam, foram capturados por homens negros de pequena estatura que os conduziram através de pântanos, até chegarem a uma cidade localizada perto de um grande rio que corria de ocidente para oriente e onde havia crocodilos. $\mathrm{Na}$ opinião de Etearco, o rio seria o Nilo (Hdt. 2. 32 33).

Perante a escassez de informações, como é seu hábito, Heródoto apresenta todas as teorias avançadas por diversos estudiosos gregos, afirmando, contudo, que estes apenas procuravam aumentar as respectivas reputações, e que, na sua opinião, duas delas não the pareciam sequer dignas de crédito. A primeira defende que os ventos etésios impedem o Nilo de correr para o mar, o que provoca a inundação. Todavia, o rio comporta-se da mesma forma quando estes não sopram. Se, de facto, fossem responsáveis pelo comportamento do rio, o mesmo aconteceria noutros rios que correm igualmente em sentido contrário aos ventos. A segunda hipótese, considerada mais ignorante do que a anterior por Heródoto, explica que o Nilo corre do Oceano, o que the permite o comportamento insólito. Apenas a terceira hipótese é considerada por ele a mais plausivel de todas, apesar de ser em simultâneo, a mais afastada da verdade ao defender que as águas do rio são provenientes do degelo das neves, o que the parece improvável, quando as zonas que percorrem são das mais quentes do mundo (Hdt. 2. 20-22).

Os habitantes das áreas cultivadas do Egipto destacam-se pelo cuidado que tomam em preservar a história de todos os povos, o que os torna por consequência o povo mais sábio encontrado por Heródoto (Hdt. 2. 77). Graças aos seus arquivos, os sacerdotes puderam mostrar-Ihe que existiram trezentas e quarenta e uma gerações humanas entre o primeiro rei e Seto, o sacerdote de Hefesto, num total de onze mil trezentos e quarenta anos. Ao longo deste período, nenhum deus tomou forma humana nem nos reinados posteriores, mas por 
quatro vezes, o sol alterou o seu curso: por duas vezes nasceu onde se põe actualmente e, outras duas, pôs-se onde nasce agora, sem no entanto, haver alterações no país como consequência (Hdt. 2. 142). Conscientes das suas conquistas enquanto povo, enumeraram-lhe ainda algumas delas. Foram os primeiros a descobrir o ano através da observação das estrelas e a dividi-lo de acordo com as estações, cada mês e cada dia estão consagrados a uma divindade, estabeleceram os epítetos dos doze deuses e ainda reclamam terem sido pioneiros a erguer altares, estátuas e templos aos deuses (Hdt. 2. 4, 82), a organizar procissões religiosas e paradas que os Gregos adoptaram (Hdt. 2. 58). A Melampo, conhecedor do ritual egípcio, ficou a dever-se a introdução do nome, culto e a procissão fálica de Dioniso entre os Gregos (Hdt. 2. 49). Também os nomes de quase todos os deuses gregos têm a sua origem no Vale do Nilo(11), excepção feita a Posídon, aos Dioscuros, a Hera, Héstia, Témis, às Graças e às Nereides. Mas, ao contrário dos Gregos, os Egípcios não prestam culto aos heróis. (Hdt. 2. 50, 52). Heródoto atribui ainda uma origem egípcia e pitagórica aos rituais órficos e báquicos, onde os iniciados não podiam ser sepultados com vestes de lã. Proibição que vigorava igualmente entre os Egípcios, que estavam igualmente impedidos de entrar nos santuários, envergando vestuário lanífero (Hdt. 2. 81).

Perante a dívida cultural que a Hélade aparentava ter para com o Egipto, não nos espanta que, durante o reinado de Psâmis, uma delegação de Eleus visitasse o Egipto, vangloriando-se de ter criado a melhor e mais justa instituição do mundo: os Jogos Olímpicos. Acreditavam que nem os próprios Egípcios, com toda a sua sabedoria superlativa, tinham ou podiam sequer comparar-se, ainda que o objectivo da sua visita fosse motivado pelo desejo de saber se estes podiam conceber um sistema mais justo do que o seu. O faraó convocou os mais sábios de entre o seu povo, que interrogaram os visitantes sobre todos os aspectos dos jogos. Informados que os cidadãos de Eleia, assim como todos os Gregos que o desejassem, podiam participar, os sábios sublinharam que essa participação dos Eleus não era totalmente justa e aconselharam-nos a abrir os Jogos a todos os atletas, mas a banir da competição os seus concidadãos (Hdt. 2. 160). A estada dos Eleus não foi a única e também a Sólon é atribuída uma estada no Vale do Nilo, de onde teria levado uma lei instituída por Amásis, ainda em vigor em Atenas ao tempo de Heródoto, que obrigava todos os Egípcios a informarem anualmente o governador da sua província do modo como ganhavam a vida, tendo decretado a pena de morte para 
os que não cumprissem a lei ou não conseguissem provar que viviam honestamente (Hdt. 2. 177).

Os visitantes mais ilustres foram, todavia, Páris e Helena, que chegaram ao Egipto arrastados pelos ventos, durante o reinado de Proteu, pouco antes do eclodir da guerra de Tróia, quando se dirigiam para a cidade do príncipe troiano. Denunciado por alguns dos seus escravos, refugiados no santuário de Héracles como suplicantes, pela violação das leis da hospitalidade enquanto se encontrava em Esparta, Páris é preso e todos são levados perante o faraó, em Mênfis. Interrogado sobre as suas origens, pátria e ainda sobre a presença de Helena, o príncipe troiano mente a Proteu e vê as suas mentiras expostas pelos seus escravos, perante o ultraje do monarca que lhe diz ser um bafejado pela sorte, por considerar importante não assassinar os visitantes, principalmente os que chegavam ao seu reino arrastados pelos ventos. De outra forma teria de pagar o terrível crime cometido depois de aceitar a hospitalidade de Menelau. Seduziu-Ihe a esposa e ainda Ihe roubou os bens. Perante esta situação, não Ihe foi permitido abandonar o Egipto com Helena e os bens roubados, que ficaram à guarda do rei até que o monarca espartano os fosse buscar, e foi-lhe dado um prazo de três dias para abandonar o país, após o que seriam tratados como inimigos. A conduta exemplar de Proteu foi, no entanto, retribuída com um acto abominável de Menelau, que não hesitou em sacrificar duas crianças egípcias para obter ventos que the permitissem navegar para Esparta (Hdt. 2. 112-115).

Se Psâmis convoca os mais sábios de entre os Egípcios, Psamético é um investigador por direito próprio, ainda que o seu reinado fique marcado por algumas peripécias. Até ao seu reinado, os Egípcios acreditavam que eram o povo mais antigo no mundo(12), após o que passaram a considerar-se a segunda raça mais antiga, logo a seguir aos Frígios (Hdt. 2. 2). Decidido a apurar a verdade na crença egípcia, Psamético realizou uma experiência "científica". Quando as suas investigações não obtiveram qualquer êxito, entregou dois recém-nascidos, de famílias humildes, a um pastor, para que os criasse entre os rebanhos, mas de modo a que nunca ninguém falasse perto deles. Deveriam viver sozinhos numa cabana remota e o pastor deveria levar- Ihes de vez em quando cabras para os alimentar com o seu leite. Estes preparativos visavam descobrir qual seria a primeira palavra pronunciada pelas crianças e, dois anos depois do início da experiência, estas aproximaram-se do pastor e estendendo as mãos teriam dito bekos. Como a situação se foi repetindo, contou finalmente o 
evento ao faraó, que pediu para que as crianças fossem levadas à sua presença. Ao ouvir a misteriosa palavra, Psamético começou de imediato a tentar descobrir que povo a utilizava no seu vocabulário. Foi-Ihe dito que era a palavra frigia para "pão" e, como resultado, os Egípcios viram-se obrigados a concluir que os Frígios eram, enquanto povo, mais antigos do que eles próprios (Hdt. 2. 2). A recolha de informações sobre esta experiência junto dos sacerdotes de Hefesto, em Mênfis, levou Heródoto a viajar para Tebas e Heliópolis, uma vez que não existiam egípcios mais eruditos do que os desta última cidade (Hdt. 2. 3). Curiosamente, esta convicção contrasta com a opinião pessoal do historiador grego, que observou que muito do território do Delta havia sido recentemente ganho pelos Egípcios, e muitas das terras ao sul de Mênfis teriam sido no passado um golfo de mar, o que the terá sido confirmado pelos sacerdotes egípcios (Hdt. 2. 10). No tempo de Min, todo o país, à excepção da província de Tebaida, era um pântano, e a área abaixo do lago Méris (localizado a uma distância de sete dias de viagem, rio acima, a partir do mar) estava submersa (Hdt. 2. 4).

As investigações de Psamético debruçaram-se ainda sobre as misteriosas origens do Nilo. Ordenou que uma enorme corda fosse tecida, para tentar sondar o fundo das nascentes (sem fundo) do rio, que o escriba do tesouro de Atena em Saís localizou entre duas montanhas de cumes pontiagudos, localizadas entre as cidades de Siene, na Tebaida, e Elefantina, conhecidas por Crófi e Mófi. Metade das águas corriam para Norte, em direcção ao Egipto, enquanto a outra metade corria para a Etiópia. Heródoto afirma, no entanto, que ficou com a impressão de que o escriba estava a brincar quando lhe deu estas informações (Hdt. 2. 28).

Depois de ter vivido exilado na Síria, devido à invasão de Sabaco, que matou o seu pai, Necao, Psamético foi trazido de volta ao Egipto pelos habitantes da província de Saís. Isso aconteceu na sequência do regresso de Sabaco à Etiópia, em consequência do sonho que the dizia para reunir todos os sacerdotes do país e cortá-los ao meio. Apercebendo-se que o sonho o tentava intimidar, para cometer sacrilégio e sofrer as terríveis consequências às mãos dos deuses e dos homens, preferiu abandonar de forma voluntária o Egipto (Hdt, 2. 139). É exilado uma segunda vez, nos pântanos, quando os onze reis que governavam o país, após o fim do reinado de Seto, o vêem cumprir, ainda que involuntariamente ao utilizar o seu capacete de bronze como copo, uma profecia que anunciava que quem de entre eles 
usasse um copo de bronze para oferecer uma libação, seria o único governante do Egipto. Consciente da injustiça sofrida às mãos dos onze reis, interrogou o oráculo de Buto que Ihe profetizou que a sua vingança seria concretizada sob a forma de homens de bronze vindo do $\operatorname{mar}^{(13)}$. Quando uns saqueadores jónios e cários são arrastados para a costa egípcia e desembarcam, envergando as suas armaduras, um egípcio correu a avisar Psamético que homens de bronze estavam a saquear a planície. Compreendendo que a profecia se havia cumprido, travou amizade com eles e persuadiu-os, com promessas de recompensas generosas, a apoiarem a sua pretensão ao trono. Desta forma, conseguiu depor os reis e apoderar-se de todo o Egipto (Hdt. 2. 152). Ainda durante a sua governação, duzentos e quarenta mil soldados egípcios, destacados nas fortalezas, decidiram por unanimidade, depois de discutirem o assunto entre si, desertar para a Etiópia, ao fim de três anos sem serem rendidos dos seus postos. Quando Psamético descobriu as suas intenções, foi atrás deles e proclamou Ihes um longo discurso ${ }^{(14)}$, através do qual tentou aplacá-los e persuadi-los a não abandonarem as divindades ancestrais, as mulheres e filhos $^{(15)}$. Como resposta, um dos soldados, de acordo com a história, apontou para os genitais e comentou que poderia ter esposas e filhos em qualquer lugar. Chegados à Etiópia, confiaram-se ao rei local, que Ihes deu em troca um presente. Alguns dos etíopes tinham-se revoltado e os egípcios foram enviados para os expulsar das suas terras, podendo depois instalar-se nelas (Hdt. 2. 30). Longe de tentar impor a sua autoridade pela força, o faraó tenta convencê-los através da persuasão e com o recurso a argumentos que encontraremos em vários dos discursos pronunciados aquando das guerras contra os Persas, procurando unir as diferentes cidades gregas contra o inimigo comum. O acto dos soldados não era inédito na história egípcia e, já aquando das campanhas de Sesóstris, alguns dos seus soldados, fatigados das conquistas, preferiram instalar-se na Cólquida, junto do rio Fásis. Esta instalação levanta algumas dúvidas a Heródoto, que uma vez mais dá uma segunda versão da história, segundo a qual teriam sido lá deixados pelo próprio faraó (Hdt. 2. 103).

O episódio evocaria certamente à audiência grega vários contextos literários e exempla que contrastam fortemente com o comportamento dos desertores, como o longo nostos de Ulisses e dos seus companheiros, que apenas ansiavam por se reunir às famílias após dez anos de guerra na planície de Tróia. Perante a resistência encarniçada dos espartanos de Leónidas nas Termópilas (Hdt. 7. 204-239), 
o abandono dos postos pelos desertores revela-se incompreensível, mas destaca a ausência das virtudes militares entre os soldados e a despreocupação com as possíveis consequências para o Egipto, ao contrário do que aconteceu entre os Persas, que preferiram ficar no seu país natal, ainda que pobre, para manterem o domínio sobre os outros povos (Hdt. 9. 122). Para estes duzentos e quarenta mil homens, o Egipto podia ser transladado para qualquer lado onde escoIhessem instalar-se, uma ideia que encontramos igualmente entre os Foceenses (Hdt. 1. 169) e os Atenienses (Hdt. 7. 143).

\section{Conclusão}

Com estes exemplos, tentámos mostrar que o livro II apenas pode ser apreendido através da intertextualidade, no contexto literário helénico da sua época. O Egipto que ali encontramos é ainda o país celebrado por Homero (Od. 3. 300, 4. 43-581, 14. 246 275, 17. 426-448), visto por um grego que nunca se considerou ou teve a pretensão de ser egiptólogo. Na gíria contemporânea, podia ser visto como um egiptomaníaco, aliás como muitos de nós, fascinado por representações de "homens de lado", um fascínio que soube transmitir à sua época e à posteridade. Parece-nos injusto criticá-lo por não responder às dúvidas que o estudo da civilização egípcia ainda nos suscita. Algumas críticas de alguns egiptólogos contemporâneos vão no sentido de censurar Heródoto por não se ter preocupado em investigar a ideologia real. Mas quantos dos actuais investigadores estão de facto em condições de abordar esse tema de modo aprofundado? Quando um aluno universitário, numa aula de Egiptologia, questionado sobre a identidade da última rainha do Egipto, afirma convicto que foi Hatchepsut, deixa-nos a pensar se no século $V$ a. $C$. o egípcio comum ou os sacerdotes poderiam estar habilitados para esclarecer as dúvidas dos turistas curiosos, principalmente quando estava em jogo a sua reputação. Os próprios documentos egípcios, como as listas reais, contradizem-se entre si na apresentação de alguns dos reinados, suprimindo outros. Maneton, tantas vezes usado como contraponto à obra do nosso historiador, apresenta nas suas listas reais muitas semelhanças com a narrativa herodotiana ao nível dos topoi. O que aliás não nos deve espantar. Há que não esquecer que Maneton, apesar de egípcio, escreveu para uma audiência grega, num Vale do Nilo governado por greco-macedónios. 
Para finalizar, gostaríamos apenas de citar um exemplo contemporâneo que nos pode ajudar a compreender as dificuldades enfrentadas por Heródoto na visita que fez ao país e na recolha de informações que levou a cabo. Há alguns anos, uma equipa de reportagem da BBC deslocou-se ao Paquistão para investigar os "crimes de honra». A jornalista entrevistou cidadãos comuns, que encontrava na rua, perguntando-Ihes apenas em que parte do Alcorão eram tais crimes sancionados. Apesar das múltiplas citações, nenhuma estava correcta. O conhecimento que demonstravam do seu livro sagrado revelou-se, quanto muito, vago, mas todos acreditavam que estavam por ele autorizados a cometer este tipo de crimes.

No final das contas, Heródoto é tão-somente o clássico que, por direito próprio e numa tarefa digna de Hércules, colocou pela primeira vez, depois do apogeu da civilização faraónica, o Egipto no mapa.

\section{Notas}

(1) A construção das personagens levanta, de facto, muitas dificuldades na análise e confronto com outros episódios das Histórias, visto, por vezes, parecerem fugir ao esquema que encontramos na composição de outras figuras. Tomemos como exemplo Rampsinito, que, de todos os monarcas a governar o país, foi o mais rico. O passo apresenta muitas semelhanças com o de Creso, igualmente famoso pela sua proverbial riqueza. O rei lídio considerava-se, graças a ela e até ao encontro com Sólon, o mais ufeliz dos homens" (Hdt. 1. 29-34). O faraó que se apresenta à primeira vista como um sério candidato a um destino igualmente trágico, devido à sua riqueza excessiva, que podiamos encarar como "hybrística", surpreende-nos pela sua relação privilegiada com a divindade. De acordo com o relato dos sacerdotes, o faraó desceu aos Infernos, onde jogou aos dados com Deméter. Ganhou uns jogos, perdeu outros e, antes de regressar, foi por ela presenteado com um lenço dourado (Hdt. 2. 122). O episódio, reverso de um topos homérico, as visitas dos deuses aos Etíopes e Hiperbóreos ou a participação nas bodas de Cadmo e Harmonia, onde se divertem na companhia dos mortais, confronta-nos com uma atmosfera descontraída, apenas comparável à descida de Dioniso aos Infernos, nas Rãs de Aristófanes, com o objectivo de resgatar Eurípides do reino dos mortos, motivado pela decadência em que o teatro tinha mergulhado em Atenas. Esta atmosfera descontraída contrasta com a catábase épica, onde Ulisses, instruído por Circe, visita a mansão de Hades, para consultar a alma de Tirésias, a quem Perséfone tinha concedido na morte o entendimento. Ulisses fá-lo na sua busca de informações para o seu regresso a Ítaca, para surpresa do próprio Tirésias (Od. 11. 92-94), Anticleia (Od. 11. 155-159) e Aquiles (Od. 11. 473-476). $\mathrm{O}$ adivinho revelou-lhe os perigos e os sofrimentos que ainda o aguardavam, a vingança que iria concretizar sobre os pretendentes, os sacrifícios a realizar e para onde partir depois de concretizada a vingança. Ulisses reencontra ainda a mãe que the revela o sofrimento e as desventuras impostas à família desde que partira para Tróia, Agamémnon, que Ihe relata a sua morte às mãos de Clitemnestra, aquando do seu regresso a Micenas e, também Aquiles, que quis saber noticias do seu filho e pai idoso. Antes de abandonar Hades, o monarca de ítaca vê ainda desfilar uma galeria de mulheres ilustres que lhe revelam a respectiva genealogia e heróis como Ájax, Minos, Tântalo, Sísifo, Héracles e Teseu (Od. 10. 490-11. 635). 
(2) Ver o extenso comentário que Ihe dedicou A. B. LLOYD, Herodotus, Book II, Leiden, 1994, que permanece como a principal obra de referência e, ainda, os artigos pertinentes de F. HARTOG, "Les Grecs Égyptologues", Annales 41/5, 1986, 953-967, e O. K. ARMAYOR, "Did Herodotus Ever go to Egypt?", JARCE 15, 1978, 59-73. S. SAUNERON, A Egiptologia, São Paulo, 1970, 7, inicia o estudo com os vários aspectos do contributo helénico para a disciplina: "a reportagem com Heródoto, a geografia com Estrabão, com Diodoro a exposição enciclopédica e com Plutarco, a filosofia e a religião".

(3) Ao longo da digressão pelo Egipto, a descrição que se faz do clima evoca o Olimpo homérico, morada dos deuses imortais onde a chuva e a neve eram desconhecidos, assim como os ventos, e onde pairava um ar límpido de uma brancura luminosa (Od. 6. 41-46). Estas condições permitiram a Asíquis construir uma pirâmide de tijolos, onde mandou inscrever uma mensagem: "não me comparem desfavoravelmente com as pirâmides de pedra. Ultrapasso-as como Zeus ultrapassa os outros deuses. Fui feita de tijolos, formados de lama recolhida com um pau quando este era mergulhado num lago" (Hdt. 2. 136).

(4) Se uma casa se incendeia, os Egípcios não tentam apagar o fogo, mas posicionam-se a intervalos ao seu redor e tentam impedir que os gatos se lancem às chamas (Hdt. 2. 66), um costume extraordinário aos olhos do "Pai da História". No Vale do Nilo, era também hábito serem as mulheres a frequentar a praça pública e a vender bens, enquanto os homens ficavam em casa a fiar (Hdt. 2. 35).

(5) Uma fonte de rendimento do tesouro real encontrava-se no lago Méris, situado nas proximidades do Labirinto. Era uma estrutura artificial, alimentada pelo Nilo, em cujo meio existiam duas pirâmides que emergiam das águas, cada uma delas coroada por uma figura de pedra, sentada num trono. Todos os dias, durante seis meses, quando a água saía do lago, este depositava um talento de prata no tesouro real, graças ao seu peixe, mas, quando a água entrava, depositava apenas vintes minas (Hdt. 2. 149)

(6) São, na opinião de Heródoto, excessivamente religiosos, mais do que qualquer outro povo no mundo (Hdt. 2. 37).

(7) Esta ideia é reforçada com a inclusão de uma lenda sobre Héracles, em tudo semelhante à inospitalidade dos Ciclopes, contada pelos Gregos, mas descartada por Heródoto, com base na total ignorância com que retrata o carácter e os costumes egípcios. Dizem que, quando visitou o pais, os Egípcios coroaram-no com grinaldas e levaram-no em procissão com a intenção de o sacrificarem a Zeus. Héracles apenas começou a resistir quando estava prestes a ser consagrado no altar, altura em que ele os massacrou a todos (Hdt. 2. 45).

(8) Encontramos este isolamento protector também na Atlântida platónica, que existe em abundância infindável e beleza maravilhosa, isolada devido a uma terramoto que a separou do resto do mundo (Plat., Crit. 108c-115d; Tim., 23d-25d).

(9) As misteriosas origens do Nilo, rio que sustenta o povo mais culto encontrado por Heródoto, parecem sugerir um contraponto para os Feaces, os mais sábios de todos os homens na navegação com naus (Od. 7. 108-109). As suas embarcações distinguem-se das demais por não necessitarem de timoneiros ou lemes, dado que elas próprias conhecem o caminho e as cidades e compreendem os pensamentos e os espíritos dos homens (Od. 8. 555-563).

(10) Uma destas cidades, Buto, localizada no braço sebenítico do Nilo, acolhe dois santuários, um dedicado a Apolo e Ártemis e o outro a Leto, que albergava igualmente o seu oráculo. Perto deste, num grande lago, existia uma itha, denominada Quémis, e que os Egípcios afirmavam ser uma ilha flutuante, ainda que Heródoto nos diga que pessoalmente nunca a viu flutuar ou mover. De acordo com a tradição, havia muito tempo que a ilha não flutuava e Leto, uma das oito divindades primigénias, que vivia em Buto, escondeu ai Apolo, que 
Ihe havia sido confiado por Ísis, quando Tífon o procurava por todo o lado, mantendo-o a salvo (Hdt. 2. 155-156). A mobilidade da ilha egípcia encontra eco na obra hímnica de Calímaco, cujo Hino a Delos (103-292) apresenta uma geografia em movimento, que, amedrontada pela ira de Hera, foge de Leto, que procurava um local onde ter Apolo. Apenas uma pequena ilha rochosa que deambulava errante pelos mares, Delos de seu nome, acedeu a ser o berço do deus, imobilizando-se finalmente no mar Egeu, imperturbável à ira da esposa de Zeus (74-81). Também aqui existia um lago, em forma de roda, mas ao contrário de Quémis é um local pobre para o arado (392, 402-403).

(11) O pais acolhe ainda oráculos consagrados a Héracles, Apolo, Atena, Ártemis, Ares, Zeus e a Leto, este último, o mais verdadeiro e respeitado de todos (Hdt. 2. 83)

(12) "Zeus pai, filho de Cronos, estabeleceu-os nos confins da terra" (Hes., Op. 168)

(13) A chegada inesperada dos saqueadores repete o mesmo topos que encontramos na chegada de Menelau ao Egipto (Od. 3. 299-300) e na história de Argantónio de Tartesso. Segundo o relato herodotiano, os foceenses foram os primeiros entre os Gregos a aventurarem-se na navegação de longo curso com os seus navios de cinquenta remos, que thes permitiram a descobertas das costas adriáticas, tirrénicas, ibéricas e ainda tartéssicas. Nestas últimas, estabeleceram laços de amizade com o monarca local, Argantónio, a quem a tradição atribui uma longevidade de cento e vinte anos e um reinado de oitenta. Ao saber da ameaça persa que pesava sobre a Foceia e incapaz de os convencer a instalarem-se no seu reino, na região que mais gostassem, deu-lhes dinheiro para rodearem a sua cidade de muralhas (Hdt. 1. 163).

(14) Também Amásis pronunciou um discurso em moldes semelhantes perante o seu povo. Como devia a ascensão ao trono à liderança da revolta contra Apriés, onde foi escolhido pelos revoltosos, e pertencia a uma família obscura, era desdenhado pelos Egípcios, que não tinham em grande conta a sua realeza. Ao contrário do que seria de esperar, o faraó não se vingou e, pela astúcia, acabou por conquistar a sua estima. Entre as suas inúmeras possessões encontrava-se um lava-pés de ouro, onde o agora faraó e os convidados para os seus jantares lavavam os pés. Resolveu derretê-la e fazer uma estátua de um deus, que mandou erguer num local estratégico onde os Egípcios costumavam ir reverenciá-la. Quando descobriu, convocou os Egípcios para uma reunião, onde Ihes contou as origens da estátua e mostrou-lhe que eles, tal como o lava-pés, tinham experiências semelhantes. Também ele fora um homem comum; mas como agora era o seu rei, deviam- Ihe igualmente respeito e era para eles razoável aceitá-lo como seu senhor (Hdt. 2. 172)

(15) Uma situação semelhante ocorre durante o reinado de Seto, um sacerdote de Hefesto. Confiante que não necessitava da classe guerreira, não tinha por ela qualquer respeito $\mathrm{e}$ retirou-Ihe as parcelas de terra, um privilégio obtido nos reinados anteriores. Como consequência, quando algum tempo depois, o Egipto foi invadido pelos Assírios, os soldados recusaram defender o país. Desesperado, o faraó dirigiu-se ao templo em busca de auxílio e adormeceu no seu interior. Num sonho, a divindade apareceu-lhe e disse-lhe para enfrentar o invasor com todos os homens que o quisessem seguir, pois nada the aconteceria e iria enviar-lhe aliados. Durante a noite, uma praga de ratos do campo invadiu o acampamento assírio e inutilizou todo o equipamento militar, forçando-o a retirar-se. Em memória deste episódio, uma estátua do rei com um rato do campo na mão podia ser vista ainda ao tempo de Heródoto, acompanhada por uma inscrição: "que todos os que me contemplam, reverenciem os deuses" (Hdt. 2. 141). 